\title{
Bram Stoker's Dracula, a Mythological reading
}

\author{
Ruxandra IVĂNCESCU ${ }^{1}$
}

This paper deals with mythological elements in Bram Stoker's novel Dracula. It discusses the mythical topos of Transylvania, seen as an exotic land, a scene for romantic events and characters. This place becomes a territory of passage, with mysterious forests, mountains, and a castle placed at the heart of the mystery. The un-dead / immortal Dracula is seen as a character of classic mythology / immortality, the story of life after death, and elements rooted in folklore - both Romanian and Irish. Because of the censorship in the Victorian Age, Bram Stoker placed the seeds of mythology encoded in his text. For his contemporaries, Dracula appears as evil and must be killed. The next generations disseminated the mythology of Dracula, each according to their cultural level and taste, from Nosferatu to The Vampire Diaries.

Keywords: Bram Stoker, Dracula, initiation, rites of passage

Bram Stoker's Dracula is not only a horror story, about terrifying monsters. The famous novel has an esoteric level, hidden deep in the adventure narrative. In fact, it is this mythological level of the text that made Dracula "immortal," a real sort of "undead" up to our days.

I read that every known superstition in the world is gathered into the horseshoe of the Carpathians, as if it were the centre of some sort of imaginative whirlpool (Stoker 2006, 8).

This "imaginative whirlpool" is the real place of Bram Stoker's writing. As for legends and superstitions, they may be familiar to Bram Stoker because of their resemblance to those in the Irish and Celtic folklore.

Transylvania is a mythological place, a no man's land or a liminal territory, part of a rite of passage. It is a land covered by dark, mysterious forests. Beyond those forests, resting on a cliff, there is a castle, the heart of the mystery. The road through the forest is actually leading to another world. Thus, Jonathan Harker's

\footnotetext{
${ }^{1}$ Transilvania University of Braşov, ruxandra.ivancescu@unitbv.ro
} 
travel to Dracula's castle is an initiation rite, similar to those found in ancient mythology and fairy tales.

Borgo Pass is, literally, a territory of passage between two worlds, as described by Arnold van Gennep (1996) in his book The Rites of Passage. There is no real coincidence in the fact that the land upon which Count Dracula's castle is placed cannot be found on normal maps:

I find that the district he named is in the extreme east of the country, just on the borders of the three states, Transylvania, Moldavia, and Bukovina, in the midst of the Carpathian Mountains; one of the wildest and least known portions of Europe. I was not able to light on any map or work giving the exact locality of the Castle Dracula. (Stoker 2006, 7-8)

Real geography and history are melting in a mythical vision of the land where ancient rituals take place. Forgotten everywhere else in Europe (or maybe not in Bram Stoker's native country, Ireland), these rituals are performed in the "Carpathian horseshoe" because they belong to this place, deeply rooted in mythology.

The time of Jonathan Harker's adventure is also an exceptional one.

It is the eve of St. George' Day. Do you not know that tonight, when the clock strikes midnight, all the evil things in the world will have full sway? Do you know where are you going, and what are you going to? (Stoker 2006, 11)

This is what the landlady of the Golden Crown inn, in Bistritz, is saying, trying to warn an ignorant traveler, the Englishman Jonathan Harker, who does not believe in superstitions.

In fact, Saint George is a feast of spring, full of rituals for good harvest and good health for people. But, as any turning point in the cosmic life, all forces, good or evil, witchcraft included, are at their plenitude.

Dracula, at his turn, is an archetype. Is he a villain, the main antagonist of the novel? Of course, he is. But we may find more interesting features behind the mask of a villain. Count Dracula is the "monster" and the master of an initiation rite at the same time. He is a magician, an old shaman, and a seducer. Generations after generations have developed or emphasized one of these features of Dracula, from the Victorian age to our days.

As far as reading Dracula as a shaman, Bram Stoker is offering us an interesting path to follow:

The Draculas were, says Arminius, a great and noble race, though now and again were scions who were held by their coevals to have had dealings with 
the Evil One. They learnt his secrets in the Scholomance, amongst the mountains over Lake Hermannstadt, where the devil claims the tenth scholar as his due. (Stoker 2006, 256)

"Scholomance" means "solomonar," a powerful shaman in the Romanian folk culture. The Dracula family learned the rites of death and rebirth from "scholomance," in the mountains, near Hermannstadt. There are a lot of tales about "solomonars"/scholomance" in the Romanian folklore. Some of them are even mentioning how the solomonar's disciples must attend a seven years' school in the underworld to become "solomonars" at their turn. Altered versions are also telling that the Devil's disciples have to undergo the same seven years underground school.

The "solomonar" version is the old one, turned into a "devilish" form by the Christian rules and rulers. A "solomonar" is a powerful shaman, known especially for his capacity to bring the rain. In fact, the "solomonar" becomes the master of a dragon and he is flying in the sky riding his dragon. He can handle the clouds and bring the rain. The dragon can be seen on the armory of the Dracula family, named after Vlad Dracul, the historic father of the historic Dracula / son of Dracul. This name is a possible popular version of the dragon name, not necessary a hint for the Devil. For Bram Stoker history was not relevant if it was not folded in fantasy and encoded in esoteric aspects. In fact, Vlad Dracul, Dracula's father, was a crusader and he wore the armory coat of the dragon.

A connection between Dracula, the literary character, and these ancient rituals is the name of the ship which brought him to England: "Demeter." Demeter is the great Goddess of the Earth in the ancient Greek mythology, mother of Core / Persephone. Is Lucy Westenra, from this mythological point of view, Persephone, Demeter's daughter, the maid kidnapped by Hades and taken to the underworld? And is Dracula the infernal bride groom, the terrible seducer?

Hades, the infernal seducer, is baptized with the name of the devil in the Christian mythology. The famous name Nosferatu, which appears in the novel, is a literary form coming from "Nefârtate," another name of the Devil in the Romanian folklore, according to Matei Cazacu $(2008,24)$. Later becoming the title name of a famous movie directed by Murnau, Nosferatu - Nefârtatu means, literally, Nobrother. He is the false, treacherous brother of God, who wants to take part in the Creation of the World. He is, in fact, an active part of the creation, as the dark side of the world, in some maniheistic legends in Romanian folklore.

C.G. Jung connects the shadow, the Devil, to the Earth and to the Great Mother; i.e. Demeter, which explains this initiation with fangs and blood. The fact that Dracula must rest in the soil of his country confirms the connection of the character with the ancient Demeter, Goddess of Earth, but also his connection with Hades, God of Inferno. 
On the other hand, Dracula's status as a magician is emphasized by his status as the master of wolves: a real shaman. The wolf is an important mythological figure in the Romanian folklore. A possible totemic animal, protective spirit, the wolf is guiding the spirit of the dead to the other world. Like his mythological brothers Cerberus and Anubis, the wolf is the guardian of the threshold between the two worlds. The old funeral songs in the Romanian folklore speak about the wolf as the guiding animal to the other world. Such a funeral lament entitled "The Song of Departure" is a real description of the path of the dead, similar to the Egyptian "Book of the Dead."

This is how it refers to the the wolf:

You go, our dear, go,

[...]

The night will fall

You'll find no host

A wolf will come your way

Don't be afraid

Make him your brother

Because the wolf knows

Every path of the forest

Every turn of the valley. ${ }^{2}$

In Bram Stoker's novel the wolves are guiding Jonathan Harker - the neophyte through the forest, to Dracula's castle. Jonathan Harker's travel to Transylvania, with a prequel in Germany, entitled "Dracula's Guest" becomes a classic initiation rite, similar to those passed by mythological and fairy tale heroes.

The initiation rite begins in the story "Dracula's Guest," where Jonathan Harker gets lost in a snow storm and is saved by a wolf. A tall man, standing on a faraway hill, is looking at the scene: he is Dracula, waiting for his guest. The story continues in Transylvania, with a plot structure that is very close to a fairy tale. Transylvania, and particularly Bargau's Pass, Dracula's place, is a no man's land, a wild place, covered by deep, mysterious forests. Here, in the dark forest, the hero has to confront his own fears, to find his magical help and cross to the other side a place of revelation, sometimes a place of eternal youth and immortality. The neophyte must die during the initiation rite in order to be reborn as an initiate.

Jonathan Harker fails at every step of the initiation rite, proving to be a false hero. The whole novel is built around this failure.

2 Brăiloiu, Constantin, Opere, Vol. V, Editura Muzicală, Bucharest, Romania, 1981, p.111, my translation. Original "Mergi, dragă, mergi/ .../ Noaptea s-a lăsa/ Gazdă n-ai afla/ Ți-a ieşi-nainte lupul înainte/ să nu te spăimânţi/ Frate tu să-I prinzi/ Căci lupul ştie seama codrilor/ Şi-a potecilor." 
Let us see the whole process, step by step. Jonathan Harker despises any advice from the locals, in both Germany and Transylvania, calling the warnings mere superstitions. In the terms of a fairy tale, he rejects the magical or spiritual help (the cross). The lawyer is too proud of his mind, of his cleverness and reason to take into account the advice of such humble people. Then, he follows his journey into the forest. The wolves are acting as guiding animals to the other world, their red eyes shine in the night around the carriage, like a circle of fire. The horses are running in the night like ghosts. In fact, the horse is another guiding animal to the other world, mentioned in the Romanian funeral song. The driver of the "caleche" performs some ritual for taming the wolves and speaks their language, as a real shaman. He is Dracula himself.

Dracula's castle, a real fortress placed above the forest, is the heart of the mystery. Here, the neophyte has to pass another classic step into an initiation rite. He has to respect an interdiction. He may enter every room of the castle, except one. Jonathan Harker enters the forbidden room and he is confronted with another initiation part: the temptation. He also fails in this process, as a false hero. The three brides of Dracula may be inspired by other mythological creatures in the Romanian folklore: "lelele," beautiful and dangerous fairies. They are extremely seductive and sometimes they punish those unhappy men disturbing their dance. Careless, J. Harker enters such a dangerous dance and he is almost destroyed by the three women vampires. The "Iele" may have been known by Bram Stoker from the Irish folklore, as the Banshees.

The cruel scene of the kidnapped child offered to the three women vampires may be a magical work, meant to test, once again, Jonathan Harker's abilities, or it can be another ritual of initiation, inspired by the ancient mythology. Some myths about Demeter or Isis tell the story of the goddess who, during her pilgrimage, arrives at a Royal Court, disguised as a humble servant woman. Here, while entering the service of the royal family, the goddess tries to initiate the young heir of the family, a newborn baby. The ritual presupposes that the child be held into the fire, in order to become immortal. The child's mother enters the room and is scared by the scene of the child put into the fire. The goddess reveals her real face and leaves the royal family without carrying on the initiation rite.

In the novel written by Bram Stoker's grand-grandson, Dacre Stoker, together with Ian Holt, a novel entitled Dracula the Un-Dead (2009, 200-201), the above-mentioned scene is otherwise seen, in a postmodernist twist. A character named Basarab who is, in fact, an avatar of Dracula is confronting Bram Stoker. His judgment about Bram Stoker's novel is ruthless. The cruel scene with the sacrificed child is considered slander, infamous accusation. In fact, after confronting the accusations of his character, Bram Stoker suffers a stroke. 
For the two young girls, Mina and Lucy, the initiation is erotic, something very subversive during the Victorian age. The entire novel is, in fact, subversive. Jonathan Harker's point of view is ironically quoted. There are many narrators in the novel, so the point of view is often changed and relatively presented. The proud Englishman of the Victorian age, who collapses in front of these "superstitions of the Carpathians" and his scientific crew are undermined permanently by the subversive discourse represented by Dracula.

As far as concerning Bram Stoker's point of view, is it close to Jonathan Harker's modern, rational speech, or is it closer to the mythology in the "Carpathian horseshoe," a place full of lore resembling the Celtic and Irish Folklore? In my opinion, the mythology of Dracula is deeply encoded in the text of the novel in order to avoid the censorship of the Victorian Age. Other novels written by Bram Stoker, like The Jewel with Seven Stars, prove the author's interest in the mystery of death and rebirth, in immortality. Dracula, the historical character, is called by Professor Van Helsing an alchemist, and, in fact, the whole initiation rite described above may be seen as an alchemical process, meant to transform the human being into something immortal or undead.

To become a vampire, one of Dracula's disciples, does not mean to be part of a simple horror story but to suffer a spiritual elevation, the human body being seen as the receptacle of the alchemic process. The sequel novel, written by Bram Stoker's descendent, follows this path of development, if not in the spiritual way, then in the evolution of its character. In fact, in this novel, Mina Harker is in love with Dracula who is the real father of her son.

The real initiate of Dracula is the reader, and generations after generations of readers gave the novel an interpretation according to the mentality of their own age. And this might also be the explanation for the long lasting success of Dracula.

\section{References}

Brăiloiu, Constantin. 1981. Opere [Works], Vol. V. București: Music Publishing House.

Cazacu, Matei. 2008. Dracula. București: Humanitas.

Ivăncescu, Ruxandra. 2004. The Paradise of Story-Telling - memory and lived reality in contemporary story-telling [Paradisul povestirii - memorie şi realitate trăită în povestirea contemporană]. Pitești: Paralela 45.

Stoker, Bram. 2006. Dracula. London: Penguin Books.

Stoker, Dacre and Ian Holt. 2009. Dracula the Un-Dead. București: Humanitas Publishing House.

Van Gennep, Arnold. 1996. Rituri de trecere. Iași: Polirom. 